\title{
Attitudes and Usage of MALL Among Saudi University EFL Students
}

\author{
Turki Rabah Al Mukhallafi ${ }^{1}$ \\ ${ }^{1}$ Department of English Language, College of Arts and Sciences, Rafha Male Campus, Northern Border \\ University, Kingdom of Saudi Arabia \\ Correspondence: Turki Rabah Al Mukhallafi, Department of English Language, College of Arts and Sciences, \\ Rafha Male Campus, Northern Border University, P. O. Box 2173, Rafha, Kingdom of Saudi Arabia. E-mail: \\ hoppy4u@hotmail.com
}

\author{
Received: August 30, 2018 Accepted: October 30, 2018 Online Published: December 31, 2018 \\ doi:10.5539/ijel.v9n1p407 \\ URL: https://doi.org/10.5539/ijel.v9n1p407
}

\begin{abstract}
Possessing distinctive features of mobility, portability, and connectivity, mobile technology has inevitably become an integrated part of everyday instructional practices and activities. Foreign language learning, especially English language, could gain substantial benefits from these advances in technology to enhance learning experiences and respond to learners' various needs and interests. There is a far-reaching investment in mobile learning projects at many Saudi Arabian universities including King Abdul Aziz University and Imam Mohammad Ibn Saud Islamic University. Moreover, the Ministry of Higher Education has a long-term plan known as "The Afaq Project" which is examining the current and future challenges for implementing online learning in all universities. Hence, the current study aims to examine students' attitudes towards and their usage of smart phones when learning English as a foreign language. A questionnaire was designed and distributed among first year university students at the Northern Border University in Saudi Arabia. It included 25 items, each with varies in responses. A systematic sampling approach was adopted to choose the participants for this study.The duration of administering the questionnaire was from November 2017 to December 2017 and it was applied to 205 students.The Statistical Package for the Social Sciences (SPSS) program was used for data analysis of the questionnaire responses. The final data were used to test the hypothesis of the research using the Chi-Squared method applied to a frequency table.Results revealed that students have positive attitudes towards using mobiles phones and that they were very interested in learning English by using technology.
\end{abstract}

Keywords: EFL Students, mobile assisted language learning (MALL), foreign language learning, attitudes towards mobile phones, usage of smart phones

\section{Introduction}

\subsection{Mobile Learning}

Mobile technologies have recently developed unique features. In addition to using regular computer technology, mobile technology possesses distinctive advantages, such as mobility, portability, connectivity, as well as ubiquity for its users (Kukulsk-Hulme \& Shield, 2008). Teachers and students have begun to integrate mobile technologies into everyday practices and activities. There has been a great deal of effort applied to designing exciting new scenarios using up-to-date technology. Language teaching and learning is one of the principal disciplines that can make full use of these updated technologies. It is taken for granted that learners and teachers can make full use of the facilities to record and listen to a range of audio material that is useful and interesting as wellbeing accessible at any time anywhere. In addition, the increasing availability of podcasts and smart mobiles promotes and encourages a variety of interactions (Agnes, 2006). Such interactions play a vital role in learning new expressions that are necessary foracquiring fluency in a foreign language.

At present, there is substantial investment in mobile learning projects at many Saudi universities including King Abdul Aziz University and Imam Mohammad Ibn Saud Islamic University. In addition, the Ministry of Higher Education has a long-term plan known as "The Afaq Project" which is examining the current and future challenges for implementing online learning in all universities. Consequently, several related infrastructure projects have been established, such as the National Center for E-Learning and Distance Learning (NCELDE), the Learning Management System (LMS), The National System for the Management of E-learning, the Saudi Digital Library, and the Medicine Program at Qasim University, which is the first M-Learning program in a 
Saudi Arabian university (Badwelan, 2016, p. 15). Such projects are a promising start to paving the way to mobile- assisted learning promotion.

\subsection{Importance of the Study}

The relevance of the study is derived from the importance of studying foreign languages, especially the English language, as it is an international language used at conferences worldwide and on the Internet. In addition, scientific research, international journals and magazines, communication, trading, business, politics, etc. are all done in English. Moreover, some foreign language teaching videos are introduced in English. Thus, English can be viewed as a means to learn additional languages. The world nowadays has witnessed tremendous progress in the world of science and technology. The rise of smart mobiles has paved the way to learn English in a variety of ways. It is a method that has proved to be interesting and attractive.

The British Council has been developing "learning English mobile resources" which is designed particularly to be used on mobile phones, and mini-computers. The products include educational materials from the Council website to be used on mobiles. The aim is to create convenient content that students could access easily and thus saving time and money as well as learning English in an effective way (Samih, 2013). In a project studying mobile devices including smart phones and mp3 players, Herrington, Herrington, Mantei, Olney \& Ferry (2009) found that these devices could be used pedagogically as cognitive tools and not just as communication devices. The researcher considers that mobile phone applications for learning English may be employed in Saudi Arabia at some later stages. Due to advances in technology in mobile phones, they have become portable computers and this increases the chance to use them as a study tool. This provides the student with a chance to use the mobile as a connection to the internet and as a source of knowledge, through online dictionaries, pronunciations, google translations and internet searches (Samih, 2013). This could complement the implementation of computer technologies in the teaching of language.

Findings of the study might be beneficial for three groups of educational experts: researchers, curriculum designers, and language teachers. Researchers could make use of the literature review provided in the study to further discuss and analyze the effects of MALL on learning. Language teachers may find inspiring and thought-provoking ideas on how to include mobile technologies in their classroom teaching practices. Curriculum designers may re-think the structure and design of the curriculum and integrate, when planning, some objectives that include the use and application of mobile phone technologies. MALL-based activities and tasks could also be integrated when designing courses and course books so that it becomes an essential part of assessing, pre-assessing, guided practice, independent practice, evaluation, and feedback.

\subsection{Literature Review}

A considerable number of recent studies have explored the usage of mobile technology to improve foreign language learning especially English language. One recent study by $\mathrm{Fu}$ and Hwang (2018) reviewed the literature on mobile technology-supported collaborative learning from 2007-2016. The study also addressed the relationship between learning strategies and measurement issues. The review highlighted the increase in research on mobile collaborative learning and the closer connection between new mobile technology and collaborative learning activities. The study also highlighted the fact that these studies tended to focus on university students and more emphasis should be devoted to elementary school students.

Hamidi and Chavoshi (2018) analyzed the use of mobile learning in university education. The study highlighted the increasing usage of mobile technologies that has improved the effectiveness of learning services allowing them to take place at any time and place. The purpose of the study was to evaluate essential factors that would lead to adoption and application of this education information system that has been created by students. The adoption of mobile learning technology in higher education was connected to factors categorized in six groups: ease of use, trust, characters and personal qualities, context, and the culture of using a research model. Results assumed that mobile learning could be a promising educational technology for development in educational environments and that a culture of using mobile applications has a positive effect on behavioral intention.

Taj, Ali, Sipra and Ahmad (2017) investigated the impact of computer assisted language learning (CALL) and mobile assisted language learning (MALL) on EFL reading comprehension at university level. Pre-formed intact groups were used to conduct this quasi-experimental study. It used a pretest and post-test control group design. The participants were 122 first year university students. Computer-based reading comprehension exercises were used as an intervention that lasted for six weeks. Vocabulary was pre-taught through WhatsApp. Post-test results of the reading comprehension achievement test revealed that the treatment group out-performed their counterparts in the control group. The results indicated the significance of incorporating technology into the language learning process. The study showed the effective use of technology in EFL reading instruction. It 
worked best when integrated into an instructional scheme. Results of the study also suggested that freely available technological resources can be used to create a conductive reading environment.

A study was recently conducted by Tzu-Ying Liu (2017) to describe the development of an English Mobile Learning attitude scale for adult learners in higher education.A preliminary version of a scale to measure attitudes toward English mobile learning was developed and piloted on 190 adult learners who were attending continuing education classes in Southern Taiwan. The full instrument was found to have both a high internal reliability coefficient $(.93)$ and significant construct validity $(\mathrm{p}<.001)$.

Asraf and Supian (2017) conducted a study on 21 undergraduates to analyze the most frequently used activities facilitating self-directed mobile-assisted vocabulary learning outside the classroom based on the pedagogical framework for mobile assisted language teaching and learning. The study also looked into the extent to which these activities enhanced the learners' metacognition. Data was collected from video reports, interviews and an activity log, and was analyzed according to the pedagogical framework for mobile assisted language teaching (Kukulska-Hulme, Norris, \& Donohue, 2015). The findings revealed that the most frequent activities utilized outside the classroom were (1) using online dictionaries to assist with understanding word meanings, (2) using video features on their phones for speaking and pronunciation practice of new words and (3) posting on social media as a means of practicing their newly acquired vocabulary in writing. The self-directed nature of these activities was reported by the participants as enhancing their metacognitive skills, resulting in increased learner confidence and greater gains in vocabulary learning.

Shih (2017) investigated the effects of teaching English for specific purposes. A total of 72 college students were randomly assigned to two groups, a language lab group and a mobile learning group, for 10 weeks of instruction. The findings revealed that the students in the mobile learning group had significant positive attitudes toward the teaching method and learning content and high user satisfaction. In addition, the learning performance of the students in the mobile learning group was better than that in the language lab group.

James Ray Edwards, Jr. (2017) explored the use of Skype as a tool for students to practice a prepared speech in a communications course to determine the perceptions of students using mobile learning to improve public speaking skills. This quantitative study examined undergraduate students' behavioral intent to use mobile learning in speech preparation. The study examined whether the intent to use mobile learning was significant and then measured behavioral intent across age groups, gender, and course experience. The results of this study supported the concept that the determinants of performance expectancy and motivation were the strongest predictors of behavioral intention in using mobile learning for speech preparation. Finally, this research study provided a greater understanding of undergraduate student acceptance and use of mobile learning for speech preparation using Skype.

Viberg and Grönlund (2017) explored the design requirements for mobile applications for second language learning in online distance higher education settings. They investigated how students used technology and how they perceived that these technologies-in-practice facilitated their language learning. Results showed that design needs to consider that (i) students use their private mobile technologies frequently when conducting self-initiated learning tasks, (ii) students' mobile technologies in practice are important, and course designers should design materials and tools for such uses, and (iii) students prefer to work on their own due to the limited time they want to devote to their learning. Consequently, in regard to the pervasive nature of mobile technology integration in society and into students' habitual use, they need various software tools on their devices to support individual learning.

The aim of Khalil's (2017) study was to develop collaborative writing using the WhatsApp among 3rd year English majors at Misr University for Science and Technology (MUST) in theFall 2017 semester. The difficulty with the study was that 3rd year English majors were not sufficiently motivated in their writing class and had trouble communicating through writing with each other during the limited time of the class. So, the idea of using WhatsApp for developing writing skills was necessary and it was especially important that there be Wi Fi available at the university. The researcher used a quasi- experimental design with two groups, experimental and control. Two instruments were used; a pre-post collaborative writing skills test and a reflection sheet. The results of the reflection sheet showed that 3rd year English majors had not used the Whats App in learning any language skill before and that they were satisfied with using it in the writing class. The writing skills test revealed that using Whats App was effective in developing collaborative writing among the participants in the study. Also, the results of the reflection sheet proved that the students in the experimental group were satisfied with using Whats App for developing collaborative writing.

Ying Liu (2016) explored the effect of positive feedback on Chinese university students' English speaking 
complexity, accuracy, and fluency in performing mobile-assisted language learning tasks. This research further extended knowledge about how Chinese students become fluent in English. The researcher adopted a matched-subject design by first matching participants to

their English proficiency level and gender, and then randomly assigning these matched sets of participants to each condition (experimental group versus comparison group). Results of the study revealed that the use of positive feedback was found to have neither a positive nor negative effect on students' speaking accuracy or fluency, but significantly improved the complexity of their speaking performance.

Wang and Cui's (2016) study provided an overview of existing research and practices about mobile-assisted language learning in China's college English education, and proposed that certain elements should be in place to ensure its successful integration. They asserted that today's college English teachers are facing more challenges than ever. Influenced by traditional Chinese culture current college English classes in China are often critiqued for their teacher-centered approach, the lack of student autonomy, as well as being biased from realistic social purposes. The use of mobile technologies in language acquisition has been explored by many researchers around the world, and has the potential to spark positive changes in China's college English education, including enhanced teacher competencies, increased learner autonomy, and improved teacher-student interaction.

Ghrieb El-Boukhari (2015) conducted a study on teachers' and students' attitudes towards the use of Mobile Assisted Language Learning (MALL) at the university of Mohamed Kheide-Biskra. The researcher hypothesized that the integration of mobile assisted learning would improve and develop the process of teaching and learning in general and language learning and teaching in particular. The researcher adapted the descriptive approach. To collect data, he used a questionnaire which was distributed randomly to teachers and students. The questionnaire design was mainly based on a literature review to enable collection of quantitative and qualitative data. The study results showed that teachers and students had a positive attitude toward the effectiveness of mobile assisted language learning. In addition, students and teachers generally agreed on the potential of mobile assisted language learning as a unique method for learning and teaching foreign languages. Mobile learning proved to be an appropriate source for listening, speaking, reading and vocabulary, which were considered the most important language skills. In addition, students showed readiness, interest and motivation to adapt their mobile devices for the purpose of learning foreign languages. Thesefindings suggest that more time, educational infrastructure, and training are required.

Miraz and Ali (2014) examined the use of SMS for vocabulary learning and its retention using 45 freshman students with upper intermediate proficiency level, lasting 16 weeks. There were 28 participants in the experimental group and they were taught 320 leading words from the Academic Word List via SMS. During the same time period the 17 control group participants were taught the same words by using a dictionary. Both groups were tested using an independent t-test. Results showed that both groups had improved in the post-test. There were no significant differences between both groups in the post-test. The results of the delayed post-test showed that SMS had more a significant effect on vocabulary retention compared to the use of a dictionary, which is clear proof that it is a pertinent way to learn a new language.

White, Jermy and Mill, Daniel(2012) investigated attitudes towards smartphone technology among Japanese university students studying English as a foreign language. It also aimed to investigate usage of smartphone technology among Japanese university students studying English as a foreign language. Data were collected from 403 Japanese university students with regard to their adoption, usage of and attitudes towards smartphones for the purpose of language learning. Findings showed that students are interested in using mobile phones when learning foreign languages as they found it easy and interesting.

AL Mukhallafi (2014) investigated the attitudes of the teachers of English in the study area of Al Madina in Saudi Arabia, in order to pave the way for the implementation of the computer and the Internet as devices of learning and teaching English in the study area. The researcher designed two tools to collect the primary data: a questionnaire and an interview. The information collected with these two tools has been statistically analysed to calculate the significant differences between responses within the participant sample of teachers. Chi-square values, degrees of freedom and levels of asymptotic significance have been calculated to help interpret the data tabulated. The main findings of the study were that Saudi Arabia is not smart in teaching English but knowledge about the basics of the computer and the Internet is up to the needed/demanded level and information about the use of the Internet at the school level is available to most teachers. Also, Teachers of English in Al Madina consider it necessary to have a computer or a laptop in the classroom, because it helps students understand and provides information and resources that are of great use in learning English as a second or foreign language. Teachers of English in the study area would welcome the idea of using the Internet in teaching English, especially at the intermediate school level. 


\subsection{Research Questions}

The study seeks to answer the following main questions:

- To what extent does the use of mobile assisted language learning develop studying English as a foreign language among Saudi university students?

- How can the attitudes towards the use of mobile assisted language learning be seen as positive among Saudi University students?

To answer these main questions, the researcher designed a questionnaire in order to collect data from the study sample. The questionnaire consists of 25 multiple-choice questions and the participants were asked to respond in the light of two main issues: their attitudes towards mobile technology in learning English as a foreign language and their usage of mobile technology in education.

\section{Method}

The present study follows the quantitative approach which uses variables to describe what is actually happening. The variable may be a construct or property in which the researcher is interested, such as age or gender (Cohen, Manion, \& Morrison, 2007). A quantitative variable may change in degree or amount.

A questionnaire was designed for distribution among university students. As defined by Kumar (2011), a questionnaire is a written list of questions with the answers to the questions recorded by the respondents. It is intended to depict the participants in an accurate way. This is a great research asset as it presents results based on the data provided.In questionnaires, the researcher does not need to personally collect data (Wilson \& Mclean, 1994). Questionnaires are also easy to administer and analyze. When planning each question the researcher must anticipate the kind of answers he or she is likely to receive. This process includes clarifying the purpose and aim of the questionnaire as well as identifying and itemizing minor topics covered by the research.

\subsection{Participants}

The participants of the study were 205 students in the first year of English department at Northern Border University in Saudi Arabia. The participants included 105 males and 100 females who aged between 18 and 20.

\subsection{Sampling Procedures}

A systematic sampling approach was adopted to choose the participants for this study. This approach was considered useful, simple and easy to be confirmed by the reader (Abu Saleh \& Avaz, 1988). In the sample, there are 105 male and 100 female EFL university students. For the questionnaire, using the systematic sampling approach, those identified respondents were given the option to voluntarily accept or reject their role as participants. The students were given the survey questionnaire together with a pencil. This gave them the chance to answer all the questions and they were also given the opportunity and privilege to withdraw at any time.

The names, along with the numbers, were recorded on a master sheet. A number was assigned to each survey packet. This number corresponded to a name on the master sheet. The above-mentioned technique was used for follow-up purposes where necessary. This procedure made it easy to establish those who responded to the questionnaire and those who did not. However, to reassure the subjects of their confidentiality, only the numbers were shown on the survey packets and not the names. The names were withheld from others and only the researcher had access to those.

\subsection{Data Collection}

The questionnaire used in the current study contains multiple-choice questions. The participants make choices in answering questions and supply basic personal information about themselves. The participants in the current study were questioned about two main issues: their attitudes towards mobile technology in learning English as a foreign language and their usage of mobile technology in education. The questionnaire was designed and conducted on first year English department students from the Northern Border University. The questionnaire consisted of 25 items investigating attitudes and how likely university students are to make use of mobile phones in EFL learning. The questionnaire was applied from mid-November to mid-December 2017.

Prior to distributing the survey instruments, ethics approval was sought from the University. Trust between a researcher and the participants of the study is important if the research is to yield results from which any valid conclusions can be drawn (Gay et al., 2009). The privacy of the respondents was respected in regard to the questionnaires. The procedure by which this was achieved has been outlined in the previous section of this chapter. This procedure ensured participants' responses to the questionnaire were chosen willingly rather than under threat of exposure, punishment, adverse consequences, actual or threatened, to coerce them into 
responding in a particular way or measure (Cohen et al., 2007).

\subsection{Research Design}

The present study follows the quantitative approach which uses variables to describe what is actually happening. The variable may be a construct or property in which the researcher is interested, such as age or gender (Cohen, Manion, \& Morrison, 2007). A quantitative variable may change in degree or amount.

\section{Results}

\subsection{Data Analysis}

This section summarizes the collected data and how data analysis is performed. Analysing data was done by using The Statistical Package for the Social Sciences (SPSS) program of the questionnaire responses. This software uses descriptive and statistical analysis according to replicated tables. The numerical coding for some responses were derived from the Likert scale reflecting the intensity of agreement or disagreement as response alternatives, managed by participants rating responses as a minimum of one (strongly agree) to a maximum of five (strongly disagree). The data collected was analysed and interpreted by classifying, categorising and ordering the units of meaning (Cohen et al., 2007), and the final data were used to test the hypothesis of the research using the Chi-Squared method applied to a frequency table. The data analysis was conducted on the questionnaire results, inductively and deductively, so as to compare the relevant concepts and issues arising in the context of approach.

The study measured two variables: the first variable was the university students' attitudes towards using mobile phones to improve their English language proficiency. The second one was their actual usage of mobile phones to improve their English language proficiency. The applied questionnaire consisted of 25 items. The following tables introduce in detail the analysis of students' responses to the questionnaire items.

Table 1. Your computer has an internet connection

\begin{tabular}{llll}
\hline & Observed N & Expected N & Residual \\
\hline Yes & 138 & 102.5 & 35.5 \\
No & 67 & 102.5 & -35.5 \\
Total & 205 & & \\
\hline \multicolumn{3}{c}{ Test statistics } \\
\hline Chi-Square & Your computer has an internet connection \\
Df & & 24.590 \\
Asymp. Sig. & & 1 & \\
\hline
\end{tabular}

Table 1 shows there is a significant difference between the observed and the expected number. One hundred thirty-eight of the observed sample agrees that their computers have an Internet connection. The Chi-Square test table shows this difference is significant because the Pearson chi-square value is 24.590 , under degree of freedom 1 and significance sig .000 (less than .05). This means their computers have an Internet connection.

Table 2. How often do you carry your mobile phone with you?

\begin{tabular}{llll}
\hline & Observed N & Expected N & Residual \\
\hline Almost never & 8 & 51.3 & -43.3 \\
Sometimes & 18 & 51.3 & -33.3 \\
Almost always & 5 & 51.3 & -46.3 \\
Always & 174 & 51.3 & 122.8 \\
Total & 205 & & \\
\hline \multicolumn{5}{l}{ Test statistics } \\
\hline Chi-Square & How often do you carry your mobile phone with you \\
Df & & 393.810 \\
Asymp. Sig. & 3 & \\
\hline
\end{tabular}

Table 2 shows there is difference between the observed and expected number in the sample. One hundred and seventy-four of the observed always carry their mobile phones. The Chi-Square test table shows this difference is significant because the Pearson chi-square value is 393, under degree of freedom 3 and significance sig .000 (less 
than .05). This means they always carry their mobile phones.

Table 3. Are you wakeful when using mobile phones in public

\begin{tabular}{llll}
\hline & Observed N & Expected N & Residual \\
\hline Very self-conscious & 112 & 41.0 & 71.0 \\
Somewhat Self conscious & 79 & 41.0 & 38.0 \\
Not sure & 7 & 41.0 & -34.0 \\
Not very self-conscious & 5 & 41.0 & -36.0 \\
Not self-conscious at all & 2 & 41.0 & -39.0 \\
Total & 205 & & \\
\hline \multicolumn{2}{l}{ Test statistics } \\
\hline Chi-Square & Are you wakeful when using mobile phones in public \\
Df & & 255.073 & \\
Asymp. Sig. & 4 & \\
\hline
\end{tabular}

Table 3 shows that there is a significant difference between the observed and the expected number. One hundred and twelve of those observed in the sample are very self-conscious and aware when using mobile phones in public. That means they are very self-conscious and aware when using mobile phones in public.

Table 4. Can you connect your phone to $\mathrm{Wi}-\mathrm{Fi}$

\begin{tabular}{llll}
\hline & Observed N & Expected N & Residual \\
\hline Yes & 199 & 102.5 & 96.5 \\
No & 6 & 102.5 & -96.5 \\
Total & 205 & & \\
\hline \multicolumn{4}{l}{ Test statistics } \\
\hline Chi-Square & \multicolumn{2}{c}{ Can you connect your phone to Wi-Fi } \\
Df & & 181.702 \\
Asymp. Sig. & & 1 & \\
\hline
\end{tabular}

From table 4 it is evident that there is a significant difference between the observed and expected numbers in the sample. One hundred and ninety-nine of those observed in the sample can connect their phones to Wi-Fi. The Chi-Square test table shows this difference is significant because the Pearson chi-square value is 181.702 under degree of freedom 1 and significance sig .000 (less than .05), meaning they can connect their phones to Wi-Fi.

Table 5. Can you use internet through a cellular network on your mobile phone

\begin{tabular}{llll}
\hline & Observed N & Expected N & Residual \\
\hline Yes & 189 & 102.5 & 86.5 \\
No & 16 & 102.5 & -86.5 \\
Total & 205 & \multicolumn{2}{c}{ Test statistics } \\
\hline \multicolumn{4}{c}{ Can you use internet through a cellular network on your mobile phone } \\
\hline Chi-Square & \multicolumn{3}{c}{} \\
Df & 145.995 \\
Asymp. Sig. & 1 & .000 \\
\hline
\end{tabular}

Table 5 shows that there is significant difference between the observed and expected number. One hundred and eighty-nine of the observed in the sample can use the Internet through a cellular network on a mobile phone. That means they can use the Internet through a cellular network on their mobile phones. 
Table 6. Which activity are you often interested in when using your mobile phone

\begin{tabular}{llll}
\hline & Observed N & Expected N & Residual \\
\hline SMS/MMS & 104 & 41.0 & 63.0 \\
Phone calls & 18 & 41.0 & -23.0 \\
Email & 11 & 41.0 & -30.0 \\
Entertainment & 62 & 41.0 & 21.0 \\
Other & 10 & 41.0 & -31.0 \\
Total & 205 & & \\
\hline \multicolumn{5}{c}{} \\
\hline Chi-Square & \multicolumn{5}{c}{ Test statistics } \\
Df & \multicolumn{3}{c}{ Which activity are you often interested in when using your mobile phone } \\
Asymp. Sig. & 165.854 & \\
\hline
\end{tabular}

In Table 6 there is a difference between the observed and expected number. One hundred and four of the observed in the sample are often interested in SMS/MMS and entertainment activities when they use mobile phones. The Chi-Square test table shows this difference is significant because the Pearson chi-square value is 165.854 , under degree of freedom 4 and significance sig .000 (less than .05); which means they are often interested in SMS/MMS and entertainment activities when they use mobile phones.

Table 7. Is it easy to install and operate third party software on a mobile phone

\begin{tabular}{llll}
\hline & Observed N & Expected N & Residual \\
\hline Completely uncomfortable & 36 & 68.0 & -42.0 \\
Somewhat comfortable & 98 & 68.0 & 30.0 \\
Completely comfortable & 80 & 68.0 & 12.0 \\
Total & 204 & & \\
\hline & & Test Statistics \\
\hline Chi-Square & Is it easy Install and operate third party software on a mobile phone \\
Df & 41.294 & \\
Asymp. Sig. & 2 & .000 \\
\hline
\end{tabular}

Table 7 shows that there is significant difference between the observed and the expected numbersin the sample. Twenty-six respondents in the sample were observed to be completely comfortable installing and operating third party software on a mobile phone. That means that they are completely comfortable installing and operating third party software on a mobile phone.

Table 8 . Do you accept receiving grades by mobile phone message

\begin{tabular}{llll}
\hline & Observed N & Expected N & Residual \\
\hline Yes & 107 & 68.3 & 38.7 \\
Sometimes & 63 & 68.3 & -5.3 \\
No & 35 & 68.3 & -33.3 \\
Total & 205 & & \\
\hline \multicolumn{4}{r}{} \\
\hline Chi-Square & & Test statistics & \\
Df & & Do you accept receiving grades by mobile phone message \\
Asymp. Sig. & & 38.556 & \\
\hline
\end{tabular}

Table 8 shows that there is a significant difference between the observed and expected number. One hundred and seven stated that they were willing to receive their grades by mobile phone message. The Chi-Square test table indicates that this difference is significant because the Pearson chi-square value is 24.590 , under degree of freedom 1 and significance sig .000 (less than .05). Thisshows they accept receiving grades by mobile phone message. 
Table 9. Do you think that studying using slides, lecture notes, and practice quizzes on your mobile phone would be helpful to your study process

\begin{tabular}{llll}
\hline & Observed N & Expected N & Residual \\
\hline Yes & 137 & 68.3 & 68.7 \\
Sometimes & 52 & 68.3 & -16.3 \\
No & 16 & 68.3 & -52.3 \\
Total & 205 & & \\
\hline \multicolumn{5}{c}{ Test statistics } \\
& \multicolumn{5}{c}{ Do you think that studying using slides, lecture notes, and practice quizzes on } \\
\hline Chi-Square & your mobile phone would be helpful to your study process \\
Df & 112.985 & \\
Asymp. Sig. & 2 & .000 \\
\hline
\end{tabular}

In table 9 there is difference between the observed and the expected number. One hundred and thirty-seven of the observed samples think that studying using slides, lecture notes, and practice quizzes on mobile phones would be helpful to their study process. That means studying using slides, lecture notes, and practice quizzes on mobile phone would be helpful to the study process.

Table 10. Could you spend time installing and using software that could make your study resources available on a mobile phone

\begin{tabular}{llll}
\hline & Observed N & Expected N & Residual \\
\hline Yes & 162 & 68.3 & 93.7 \\
Sometimes & 30 & 68.3 & -38.3 \\
No & 13 & 68.3 & -55.3 \\
Total & 205 & & \\
\hline & & Test statistics & \\
& & Could you spend time installing and using software that could make \\
\hline Chi-Square & your study resources available on a mobile phone \\
Df & & 194.702 & \\
Asymp. Sig. & 2 & .000 \\
\hline
\end{tabular}

Table 10 shows that there is significant difference between the observed and the expected number. One hundred and sixty-two of the observed samples spend time installing and using software that makes study resources available on a mobile phone. That means they spend time installing and using software to make study resources available on their mobile phones.

Table 11. Do you think that some mobile applications would help you achieve some success in your courses

\begin{tabular}{llll}
\hline & Observed N & Expected N & Residual \\
\hline Yes & 159 & 68.3 & 90.7 \\
Not sure & 33 & 68.3 & -35.3 \\
No & 13 & 68.3 & -55.3 \\
Total & 205 & & \\
\hline \multicolumn{4}{c}{ Test statistics } \\
\hline Chi-Square & Do you think that some mobile applications would help you achieve \\
Df & \multicolumn{2}{c}{ some success in your courses } \\
Asymp. Sig. & 183.376 & \\
\hline
\end{tabular}

From table 11 it can be seen that there is a significant difference between the observed and the expected number. One hundred and fifty-nine respondents think some mobile applications would help them achieve greater success in their courses. This means some mobile applications would help the students achieve greater success in their courses. 
Table 12. Have you ever tried learning videos or course on your mobile phone

\begin{tabular}{llll}
\hline & Observed N & Expected N & Residual \\
\hline Yes & 170 & 102.5 & 67.5 \\
No & 35 & 102.5 & -67.5 \\
Total & 205 & & \\
\hline \multicolumn{4}{c}{ Test statistics } \\
\hline Chi-Square & Have you ever tried learning videos or course on your mobile phone \\
Df & & 88.902 & \\
Asymp. Sig. & & 1 & .000 \\
\hline
\end{tabular}

Table 12 reveals a significant difference between the observed and the expected number. From the sample, one hundred and seventy had tried learning videos or courses on their mobile phones, meaning that they had tried using learning videos or courses on their mobile phones.

Table 13. Can you easily find information on the internet

\begin{tabular}{llll}
\hline & Observed N & Expected N & Residual \\
\hline Yes & 184 & 68.3 & 115.7 \\
Sometimes & 16 & 68.3 & -52.3 \\
No & 5 & 68.3 & -63.3 \\
Total & 205 & & \\
\hline \multicolumn{4}{r}{} \\
\hline Chi-Square & Test statistics \\
Df & Can you easily find information on the internet \\
Asymp. Sig. & 294.566 \\
\hline
\end{tabular}

In table 13 there is significant difference between the observed and expected number in the sample. One hundred and eighty-four of those observed in the sample could easily find information on the Internet. The Chi-Square test table shows this difference is significant because the Pearson chi-square value is 294.566 , under degree of freedom 2 and significance sig .000 (less than .05). This shows they can easily find information on the Internet.

Table 14. Are you comfortable using the different features of your cell phone

\begin{tabular}{llll}
\hline & Observed N & Expected N & Residual \\
\hline Yes & 18 & 102.5 & 79.5 \\
No & 23 & 102.5 & -79.5 \\
Total & 205 & & \\
\hline \multicolumn{3}{r}{} & Test statistics \\
\hline Chi-Square & \multicolumn{2}{c}{ Are you comfortable using the different features of your cell phone } \\
Df & & 123.322 \\
Asymp. Sig. & & 1 & \\
\hline
\end{tabular}

Table 14 shows that there is significant difference between the observed and the expected number. One hundred and eighty-two of those observed in the sample are comfortable using the different features of cell phones. The Chi-Square test table indicates that this difference is significant because the Pearson chi-square value is 123.322 , under degree of freedom 1 and significance sig .000 (less than .05). This means they are comfortable using the different features of cell phones. 
Table 15. Can you easily figure out the new features of a cell phone

\begin{tabular}{llll}
\hline & Observed N & Expected N & Residual \\
\hline Yes & 176 & 103.0 & 73.0 \\
No & 30 & 103.0 & -73.0 \\
Total & 206 & & \\
\hline \multicolumn{3}{r}{} \\
\hline Chi-Square & Test statistics \\
Df & Can you easily figure out the new features of a cell phone \\
Asymp. Sig. & 103.476 \\
\hline
\end{tabular}

From table 15 it is clear there is a difference between the observed and the expected number of the sample. One hundred and seventy-six of those observed in the sample said that it is easy to figure out the new features on a cell phone. This means it is easy to figure out the new features of a cell phone.

Table 16. Are you interested in learning English using your mobile phone

\begin{tabular}{llll}
\hline & Observed N & Expected N & Residual \\
\hline Yes & 175 & 102.5 & 72.5 \\
No & 30 & 102.5 & -72.5 \\
Total & 205 & & \\
\hline \multicolumn{3}{c}{ Test statistics } \\
\hline Chi-Square & Are you interested in learning English using your mobile phone \\
Df & & 102.561 \\
Asymp. Sig. & 1 & .000 \\
\hline
\end{tabular}

Table 16 shows there is significant difference between the observed and expected numbers in the sample. One hundred and seventy-five of the observed were interested in learning English using a mobile phone. This means they are interested in learning English using a mobile phone.

\section{Discussion}

The review of studies regarding MALL reveals the various uses of smart mobile phone applications to enhance learning, especially learning English as a foreign/second language. The analysis of data reveals that most students already carry smart phones that are always connected to the Internet. They welcomed using mobile phones to communicate with professors in the learning community, receiving grades on assignments and feedback on projects. Students showed positive attitudes towards studying and doing quizzes on their mobile phones. They were aware of applications to install that could make courses easier to study. Students were intensely interested in learning English using mobile phones.

This section evaluates and interprets results with respect to study hypotheses and in relation to previous work. The two main questions of the study were:

The first question: to what extent has the use of MALL developed studying English as a foreign language among Saudi University students over the academic year?

To answer this question, the students' responses regarding using mobiles in downloading applications to help learning English were analyzed using a Chi-square Test. Results in previous section concerning students' usage (Tables $9,11,12,13$ ) showed that students were comfortable installing and operating third party software on their mobile phones.

In regard to the usage of MALL in EFL, some studies have focused on the use of MALL applications such as WhatsApp to teach EFL vocabulary. The study conducted by Taj, Ali, Sipra and Ahmed (2017) integrated MALL with computer assisted language learning (CALL). In this study WhatsApp as a MALL application was used to preteach vocabulary before an EFL reading comprehension activity. The study of Asraf and Supian (2017) also utilized MALL to support self-learned vocabulary outside the classroom with university students. Both studies revealed an improvement in EFL reading instruction as well as an enhancement of metacognitive skills. "WhatsApp" has not been used solely for teaching vocabulary, but was also employed in Khalil's study (2017) to improve collaborative writing among university students. In the current study, the majority of the students affirmed 
that they enjoyed trying out new technology and that they found it easy to use new software. They thought that some mobile applications would help them achieve greater success in their EFL courses. They also stated that they spent time in the study area installing and using software that could make study resources available on their mobile phones. Therefore, "WhatsApp" as one form of new technology, could be integrated and employed into EFL courses to increase students' motivation and encourage collaborative work.

The second question: How have the attitudes towards the use of mobile assisted language learning been positive among Saudi University students?

To answer this question, the students' responses in relation to their attitudes towards using mobiles in downloading applications to help learning English were analyzed using the chi-square test. Results in previous section concerning students' attitudes (Tables 1, 2, 5, 6, 7) showed that students have positive attitudes towards installing and operating third party software on their mobile phones to improve their English language learning.

Concerning the attitudes towards MALL for EFL, recent studies such as those by Tzu-Ying (2017) and Viberga (2017) have examined higher education students' attitudes towards MALL and how technology facilitated their second language learning. The results reveal how mobile phones are considered essential tools for self-initiated learning tasks and that students prefer to work on MALL activities especially when working on their own. Another study by Wang and Cuis (2016) conducted an overview of recent research on MALL and suggested that MALL has significant application for enhancing teacher competencies, increasing learner's autonomy, and improving teacher-student interaction. In the present study, students have shown that they do not mind texting their professors in the learning community. They also welcomed receiving tasks, activities, assignments, and quizzes on their cell phones. They also don't object to receiving grades and marks via cell phones, especially when marks are individually and confidentially delivered. Students think that studying using slides, lecture notes, and practice quizzes on mobile phones would be helpful in their study process.

Further studies have emphasized the positive effect of MALL on learners' attitudes and content learning and high user satisfaction. These studies assume that MALL activities and tasks are more effective than language lab activities and tasks. The results of the current study support the view that most of the students in the study area are interested in learning using their mobile phones. The students reported that they always carry their mobile phones and that they are comfortable using the different features of their mobile phones. Moreover, they can easily figure out the new features of a cell phone, which is easier and less time consuming than performing language lab activities.

Results of the study revealed that students have positive attitudes towards using mobiles phones in learning. They are interested in downloading mobile phone applications that could enhance their learning process. They are also keen on learning English using mobile phone technology. They are willing to work on English learning applications and get online feedback from their professors, which make courses easier to study.

Further studies may examine pre-university students' attitudes and usage of smart phones when learning English as a foreign language. Studies may focus on improving specific English language skills using specific mobile phones apps. Future studies may investigate improving EFL using social network apps; especially for vocabulary leaning.

\section{References}

Abu Saleh, M. S., \& Avaz, A. M. (1985). Introduction to statistics. Irbid, Jordan: Al Yarmouk University.

Al Mukhallafi, T. (2014). Computer Assisted Language Learning For Learning English In Saudi Arabia, UTS. PHD Thesis.

Asraf, R. M., \& Supian, N. (2017). Metacognition and Mobile-Assisted Vocabulary Learning. Arab World English Journal, 8(2). https://doi.org/10.24093/awej/vol8no2.2

Badwelan, A., Drew, S., \&Bahaddad, A. A. (2016). Towards acceptance m-learning approach in higher education in Saudi Arabia. International Journal of Business and Management, 11(8), 12. https://doi.org/10.5539/ijbm.v11n8p12

Cohen, L., Manion, L., \& Morrison, K. (2007). Research methods in education (6th ed.). London: Routledge.

Edwards Jr, J. R. (2017). Undergraduate Student Acceptance and Use of Mobile Learning in Speech Preparation Using Skype (Doctoral dissertation, Indiana State University). Retrieved from https://search.proquest.com/openview/8235437a5504cb84e8eebf004c6a0abe/1?pq-origsite=gscholar\&cbl=1 $8750 \&$ diss $=\mathrm{y}$

Fu, Q. K., \& Hwang, G. J. (2018). Trends in mobile technology-supported collaborative learning: A systematic review of journal publications from 2007 to 2016 . Computers \& Education. 
https://doi.org/10.1016/j.compedu.2018.01.004

Gay, L. R., Mills, G. E., \& Airasian, P. (2009). Educational research competencies for analysis and applications (9th ed.). London: Pearson Education International.

Ghrieb, E. B. (2015). Teachers' and Students' Attitudes Towards the Use Mobile Assisted Language Learning. Mohamed Kheider University of Biskra, Algeria.

Hamidi, H., \& Chavoshi, A. (2017). Analysis of the essential factors for the adoption of mobile learning in higher education: A case study of students of the University of Technology. Telematics and Informatics. https://doi.org/10.1016/j.tele.2017.09.016

Herrington, J., Herrington, A., Mantei, J., Olney, I., \& Ferry, B. (2009). New technologies, new pedagogies: Using mobile technologies to develop new ways of teaching and learning. In J. Herrington, A. Herrington, J. Mantei, I. Olney, \& B. Ferry (Eds.), New Technologies, new pedagogies: Mobile learning in higher education (pp. 1-14). Wollongong: University of Wollongong.

Khalil, H. (2017). Using Whats App for Developing Collaborative Writing among English Majors at MUST. Journal of Research in Curriculum, Instruction and Educational Technology, 3(3).

Kukulska-Hulme, A., \& Shield, L. (2008). An overview of mobile assisted language learning: From content delivery to supported collaboration and interaction. ReCALL, 20(3), 271-289. https://doi.org/10.1017/S0958344008000335

Kukulska-Hulme, A., Norris, L., \& Donohue, J. (2015). Mobile pedagogy for English language teaching: a guide for teachers.

Kumar, R. (2011). Research Methodology: A Step-by-Step Guide for Beginners (3rd ed.). New Delhi: Sage.

Liu, T. Y. (2017). Developing an English mobile learning attitude scale for adult learners. Journal of Educational Technology Systems, 45(3), 424-435. https://doi.org/10.1177/0047239516658448

Liu, Y. (2016). Improving Chinese University Students' Speaking Performance in Mobile-Assisted English Learning (Doctoral dissertation, University of Illinois at Chicago). Retrieved from https://search.proquest.com/openview/0c0f267a5b4e4bcf2a765610324ae479/1?pq-origsite=gscholar\&cbl=1 8750\&diss $=\mathrm{y}$

Miraz, S., \& Ali, M. (2014). An overview of mobile assisted language learning (MALL). In International Conference on eBusiness, eCommerce, eManagement, eLearning and eGovernance (Vol. 1, No. 1).

Samih, M. (2013, May). How I learn. Al-Ahram Weekly, 1167, 9-15. Cairo, Egypt.

Shih, R. C. (2017). The Effect of English for Specific Purposes (ESP) Learning-Language Lab versus Mobile-Assisted Learning. International Journal of Distance Education Technologies (IJDET), 15(3), 15-30. https://doi.org/10.4018/IJDET.2017070102

Taj, I. H., Ali, F., Sipra, M. A., \& Ahmad, W. (2017). Effect of Technology Enhanced Language Learning on EFL Reading Comprehension at Tertiary Level. Arab World English Journal, 8(1). https://doi.org/10.7575/aiac.ijalel.v.6n.3p.262

Viberg, O., \& Grönlund, A. (2017). Understanding students' learning practices: challenges for design and integration of mobile technology into distance education. Learning, Media and Technology, 42(3), 357-377. https://doi.org/10.1080/17439884.2016.1088869

Wang, Z., \& Cui, Y. (2016). Mobile-Assisted Language Learning in China's College English Education: The Reality and Research. In Mobile Learning Design (pp. 335-349). Springer Singapore. https://doi.org/10.1007/978-981-10-0027-0_20

White, J., \& Mills, D. J. (2014). Examining attitudes towards and usage of smartphone technology among Japanese university students studying EFL. CALL-EJ, 15(2), 1-15. Retrieved from http://www.callej.org/journal/15-2/White_Mills_2014.pdf

Wilson, N., \& Mclean, S. (1994). Questionnaire design: A practical introduction. Newtown Abbey, Co. Antrim: University of Ulster Press.

Yükselir, C. (2017). A Meta-Synthesis of Qualitative Research About Mobile Assisted Language Learning (MALL) In Foreign Language Teaching. Arab World English Journal (AWEJ), 8(3). https://doi.org/10.2139/ssrn.3053570 


\section{Copyrights}

Copyright for this article is retained by the author, with first publication rights granted to the journal.

This is an open-access article distributed under the terms and conditions of the Creative Commons Attribution license (http://creativecommons.org/licenses/by/4.0/). 